\title{
TANTANGAN KEPEMIMPINAN MANAJERIAL ORGANISASI PERGURUAN TINGGI, PREDIKTOR EFISIENSI MANAJEMEN SISTEM PENDIDIKAN NASIONAL
}

\begin{abstract}
Alex Rumondor
Abstract

In accordance to the Republic of Indonesia Law of National Education System which is known as "Sisdiknas"(Sistem Pendidikan Nasional) Law Number 20, Year 2001, the national education system in Indonesia should guarantee the universities management efficiency. Besides other factor of universities' capability to implement the autonomy of universities organizational management; either in academic, personal, financial fields or in other functional areas regulated by each university. Following the government regulation Law Number 99 Year 2001 concerning the Education National Standard, normatively in fact that law is challenging the universities organizational management locally, nationally and globally and today this become the object of study of the organizational communication. Our contemporary understanding actually has accepted that leadership is basically influence the daily interpersonal communication in the life of organization even it determines the achievement of organization's objectives. No motivation found among universities' leaders is often caused of dissension in the managing leadership of the organization.
\end{abstract}

Keywords: Managing Leadership, Universities Organization, National Education System.

\section{Latar Belakang Masalah}

Organisasi perusahaan dewasa ini berada di tengah-tengah transformasi yang revolusioner dari persaingan abad industri bergeser ke persaingan abad informasi (Kaplan Robert. S. dan David P. Norton, 1996) dengan demikian organisasi perusahaan tidak memadai lagi menggunakan berbagai ukuran finansial dalam menciptakan nilai masa depan perusahaan melalui investasi pada pelanggan, pemasok, pekerja, proses teknologi dan inovasi. Para eksekutif senior organisasi perusahaan lalu menggunakan sistem manajemen strategis "Balance Score Card" menerapkan strategi menjadi aksi sebagai kerangka kerja tindakan strategis penting perusahaan, antara lain dalam proses umpan balik pembelajaran atau pengalaman belajar dan pertumbuhan perusahaan yang meliputi tiga kategori strategis utama: (1) motivasi kerja; (2) kapabilitas sistem informasi dan (3) motivasi pemberdayaan dan keselarasan; dan mencakup pula tujuan pekerja yang ditarik dari tiga pengukuran utama: (1) kepuasan kerja; (2) retensi pekerja; dan (3) produktivitas kerja. Tujuan kepuasan kerja umumnya dipandang sebagai pendorong kedua pengukuran lainnya pada sub (1) dan sub (2). Sedangkan faktor yang mempengaruhi kepuasan pekerja adalah kompetensi staf, infrastruktur teknologi dan iklim untuk bertindak. 
Kepemimpinan manajerial dan gaya kepemimpinan organisasi perguruan tinggi, dalam bentuk organisasi jasa, juga menggunakan sistem manajemen strategi pendidikan nasional berdasarkan Panca Sila dan Undang-Undang Dasar Negara Republik Indonesia Tahun 1945 yang berakar pada nilai-nilai agama, kebudayaaan nasional Indonesia dan tanggap terhadap tuntutan zaman (Pasal 1: Undang-Undang RI No. 20 Tahun 2003 tentang Sistem Pendidikan Nasional). Struktur dan manajemen perguruan tinggi yang berlangsung dalam hubungan keterkaitan interaktif komunikasinya, selalu dihadapkan pada faktor manusia, baik di dalam proses komunikasi organisasi internal maupun eksternal. Termasuk faktor-faktor diluar kendali manajer itu sendiri yaitu kondisi lingkungan (Sondang, Siagian, 1983:20-31) faktor politik, ekonomi dalam organisasi, negara, faktor fisik dan sosial serta faktor teknologi.

Menyoroti masalah manajemen sistem pendidikan nasional R.I. bertepatan dengan peringatan hari Proklamasi Kemerdekaan R.I. ke 66 - , mengingatkan kita kepada tantangan kepemimpinan yang dialami tiap jenjang pendidikan: Pendidikan Dasar dalam bentuk SD dan Madrasah Ibtidaiyah yang melandasi jenjang pendidikan menengah; Pendidikan Menengah merupakan lanjutan pendidikan dasar yang terdiri atas Pendidikan Menengah Umum dan Pendidikan Menengah Kejuruan (SMA, MA, SMK, MAK); Pendidikan Tinggi, merupakan jenjang pendidikan setelah pendidikan menengah yang mencakup program Pendidikan Diploma, Sarjana, Magister, Spesialis dan Doktor yang diselenggarakan oleh pendidikan tinggi.

Berbagai bentuk pendidikan tinggi seperti akademi, politeknik, sekolah tinggi, institut, dan universitas Umumnya menghadapi tantangan yang sama yaitu kecenderungan komersialisasi manajemen, akademik, operasional, personalia, keuangan, yang pada gilirannya mengganggu kebebasan dan kemandirian yang dituntut oleh manajemen sistem pendidikan nasional (Pasal 49 ayat 2 P.P. RI No. 19 Th 2005 tentang Standar Nasional Pendidikan) -- sebagai prediktor efisiensi manajemen sistem pendidikan nasional itu sendiri.

Rata-rata ujian negara di jenjang pendidikan dasar, menengah mengalami gangguan baik pengumuman hasilnya, proses belajar siswa serta kasus "nyontek" soal-soal ujian dibawah kendali Guru sekolah dan Panitia ujian seperti kejadian di Jawa Timur. Pada gilirannya kasus ini berdampak negatif terhadap mekanisme, persediaan dan instrumen penilaian hasil belajar peserta didik (Pasal 1 buku 11 P.P. RI No 19 Thn 2003 Ketentuan Umum standar penilaian). Masih banyak lagi kasus-kasus lain seperti penetapan biaya masuk sekolah yang "memperdagangkan" formulir masuk di jenjang pendidikan menengah. Turun naiknya penerimaan mahasiswa di perguruan tinggi swasta umumnya pada tiap tahun akademik juga merupakan tantangan kepemimpinan manajerial perguruan tinggi.

Semua faktor dari kasus-kasus yang mempengaruhi efisiensi dan produktifitas kerja inilah yang disebut tergolong indikator tantangan kepemimpinan yang dihadapi dunia pendidikan nasional dewasa ini.

Tantangan kepemimpinan manajerial yang sering dibahas dalam kebanyakan organisasi (R. Wyne Pace dan F. Faules, 2002: 276. Editor Deddy Mulyana M.A. Ph. D.) antara lain karena kurang atau tidak adanya motivasi dari 
pimpinan. Motivasi merujuk kepada kebutuhan sebagai kekuatan pendorong perilaku "bawahan", menemukan dua peringkat kegiatan yang memuaskan kebutuhan manusia; (1) kebutuhan yang berkaitan dengan kepuasan kerja, (2) kebutuhan yang berkaitan dengan ketidakpuasan kerja. Faktor-faktor yang mempengaruhi kebutuhan kerja itulah yang disebut indikator tantangan kepemimpinan. Tantangan kepemimpinan inilah yang sering dihadapi organisasi perguruan tinggi dengan munculnya gejala tidak adanya motivasi, yaitu produktivitas rendah, kemangkiran, moral rendah, dan kemunduran. Sedangkan di sisi lain tujuan kepemimpinan manajerial perguruan tinggi justru untuk membantu orang dalam menegakkan, mempertahankan dan meningkatkan motivasi mereka. Apalagi prinsip organisasi perguruan tinggi adalah menggunakan pendekatan manajemen sistem pendidikan nasional berdasarkan kebebasan akademik, otonomi, dan kemandirian. Pendekatan kesisteman dalam organisasi adalah prinsip fungsionalisasi yang mendasar karena implikasinya yang amat luas (Sondang P, Siagian,1982:95). Bahkan dapat dikatakan bahwa atas dasar pelaksanaan fungsionalisasi secara efektiflah mekanisme kerja akan mantap, hubungan kerja akan serasi dan koordinasi akan berjalan sedemikian rupa, sehingga terwujudlah pelaksanaan tugas secara efisien, efektif, ekonomis dan produktif.

Produktivitas dengan penggunaan model "input-transformasi dan output" (Sondang P. Siagian,1983:93), jelas terlihat bahwa meningkatkan efisiensi kerja dalam organisasi bukan sekedar melakukan penghematan dalam penggunaan dan pemanfaatan sumber daya yang tersedia. Peningkatan efisiensi amat erat hubungannya dengan peningkatan produktifitas kerja, baik ditinjau dari sudut pandang organisasi sebagai keseluruhan, maupun dilihat dari segi prestasi kerja orang per orang di dalam organisasi. Transformasi "input" menjadi produk, oleh karenanya, tidak hanya ditujukan terhadap usaha penghematan dan penghindaran berbagai jenis pemborosan, akan tetapi juga ditujukan kepada optimalisasi, dan kalau mungkin maksimalisasi, produk yang dihasilkan oleh organisasi, baik dalam bentuk barang maupun dalam bentuk jasa.

Kehidupan proses komunikasi organisasional manajerial dan gaya kepemimpinan perlu selalu dilihat dari tiga dimensi: masa lalu, masa kini, dan masa depan (Sondang P. Siagian 1982: 112-114). Dengan demikian, pengambilan keputusan yang diambil sekarang dan memang dimaksudkan untuk memecahkan berbagai masalah tantangan dan risiko yang muncul. Dan tidak akan ada seorang pun yang akan berani menjamin bahwa masalah yang serupa atau sejenis tidak akan timbul lagi dikemudian hari. Dikatakan risiko oleh karena betapapun cermatnya seseorang mempelajari masa kini dan mengaitkannya dengan faktorfaktor yang mungkin sangat berpengaruh terhadap arah situasi yang akan timbul dimasa depan, tidak dapat menjamin "ramalan masa depan yang akan terjadi". Faktor-faktor pengaruh dalam pengambilan keputusan kepemimpinan manajerial inilah pula yang digolongkan sebagai indikator tantangan kepemimpinan.

Kepemimpinan dan komunikasi didalam organisasi dan manajerial perguruan tinggi adalah dua faktor yang saling terkait dalam manajemen komunikasi organisasi. Kepemimpinan terdiri dari pencapaian pengaruh antar pribadi (antarpersona) melalui (proses) komunikasi yang dilakukan seorang 
pemimpin, yang dapat memberikan pengaruh dalam bentuk verbal dan nonverbal secara persuasif. Bawahan dan penyelia atau supervisor saling memahami dan menghasilkan komunikasi yang efektif. Bilamana bawahan tidak berperilaku seperti yang supervisor inginkan, maka akan menghasilkan kepemimpinan yang tidak efektif.

Dengan demikian, apabila kita membahas organisasi perguruan tinggi, didalamnya tercakup adanya proses komunikasi. Jadi jelas, tanpa komunikasi tidak ada organisasi. Disisi lain sebagian penulis berpendapat bahwa manajemen adalah komunikasi.

Jadi memahami tujuan utama komunikasi di lingkungan organisasi perguruan tinggi disisi lain adalah memperbaiki organisasi. Memperbaiki organisasi biasanya ditafsirkan sebagai "memperbaiki hal-hal untuk mencapai tujuan manajemen" (R. Wayne Pace, 2002: 24-25). Dengan kata lain, orang mempelajari komunikasi organisasi, untuk menjadi manajer yang lebih baik. Sebaliknya kita sering mendengar mahasiswa berkata bahwa mereka tertarik mempelajari komunikasi organisasi karena pengalaman mereka yang menyulitkan dalam organisasi. Sebagian besar ketidakpuasan mereka nampaknya bersumber dari perasaan mereka bahwa sistem organisasi tersebut kurang personal dan mengekang kreativitas dan produktivitas. Mereka berpendapat bahwa organisasi perlu memperbaiki kualitas hidup ditempat kerja. Mereka agaknya melihat organisasi dari perspektif seorang pekerja, dan tertarik pada apa yang dilakukan organisasi terhadap orang. Alasan mereka untuk mempelajari komunikasi organisasi adalah untuk menentukan cara-cara yang dapat memperbaiki kualitas kehidupan mereka.

Gambar 1 : Denah Organisasi Menunjukkan Enam Tingkat Manajemen dan Satu

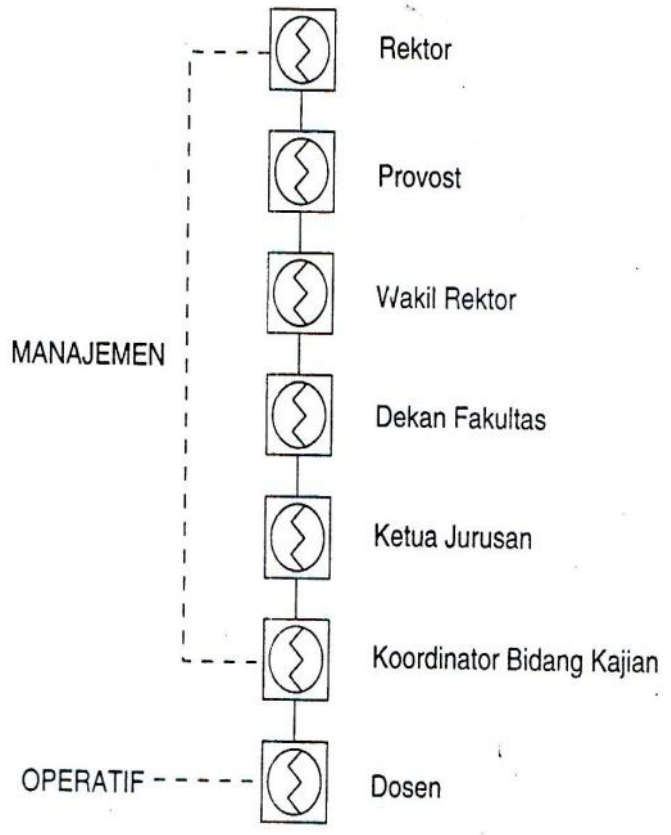


Biasanya kita beranggapan (R. Wayne Pace, 2002: 184-185) bahwa informasi bergerak dari manajemen kepada para pegawai; namun, dalam organisasi termasuk organisasi perguruan tinggi kebanyakan hubungan ada pada kelompok manajemen. Gambar 1 menunjukkan bagaimana struktur komunikasi sebuah universitas (perguruan tinggi) mempunyai enam tingkat manajemen dan hanya satu tingkat operatif.

Dapat dilihat juga bagaimana titik berat hubungan dalam komunikasi organisasi perguruan tinggi atau universitas seringkali bergerak ke arah komunikasi manajerial yang perhatian utamanya adalah komunikasi ke bawah, membawa informasi melalui kelompok manajemen dan kepada kelompok operatif para dosen. Ada dua masalah utama; (1) jenis informasi apa yang disebutkan dari tingkat manajemen kepada para pegawai dan (2) bagaimana informasi tersebut disediakan. Ada lima informasi yang biasa dikomunikasikan dari atasan kepada bawahan. (1) informasi mengenai bagaimana melakukan pekerjaan, (2) informasi mengenai dasar pemikiran untuk melakukan pekerjaan, (3) informasi mengenai kebijakan dan praktek organisasi, (4) informasi mengenai kinerja pegawai, (5) informasi untuk mengembangkan rasa memiliki tugas (sense of mission). Para pegawai diseluruh tingkat dalam organisasi merasa perlu diberi informasi termasuk informasi operatif bagi para Dosen yang kecenderungannya kurang mendapat informasi dari kelompok manajemen perguruan tinggi. Manajemen puncak hidup dalam dunia informasi dari semua unit dalam organisasi dan harus memperoleh informasi untuk semua unit. Aliran informasi dan manajemen puncak yang turun ke tingkat operatif, merupakann aktivitas yang berkesinambungan dan sulit. Pemilihan cara menyediakan informasi mencakup tidak hanya pengeluaran sumber daya langsung moneter tetapi juga sumber daya psikis dan emosional.

Dapat dilihat juga bagaimana titik berat hubungan dalam komunikasi organisasi perguruan tinggi atau universitas seringkali bergerak ke arah komunikasi manajerial yang perhatian utamanya adalah komunikasi ke bawah, membawa informasi melalui kelompok manajemen dan kepada kelompok operatif para dosen. Ada dua masalah utama; (1) jenis informasi apa yang disebutkan dari tingkat manajemen kepada para pegawai dan (2) bagaimana informasi tersebut disediakan. Ada lima informasi yang biasa dikomunikasikan dari atasan kepada bawahan. (1) informasi mengenai bagaimana melakukan pekerjaan, (2) informasi mengenai dasar pemikiran untuk melakukan pekerjaan, (3) informasi mengenai kebijakan dan praktek organisasi, (4) informasi mengenai kinerja pegawai, (5) informasi untuk mengembangkan rasa memiliki tugas (sense of mission). Para pegawai diseluruh tingkat dalam organisasi merasa perlu diberi informasi termasuk informasi operatif bagi para Dosen yang kecenderungannya kurang mendapat informasi dari kelompok manajemen perguruan tinggi. Manajemen puncak hidup dalam dunia informasi dari semua unit dalam organisasi dan harus memperoleh informasi untuk semua unit. Aliran informasi dan manajemen puncak yang turun ke tingkat operatif, merupakann aktivitas yang berkesinambungan dan sulit. Pemilihan cara menyediakan informasi mencakup tidak hanya pengeluaran sumber daya langsung moneter tetapi juga sumber daya psikis dan emosional. 
Komunikasi ke bawah dalam sebuah organisasi berarti bahwa informasi mengalir dari jabatan berotoritas lebih tinggi kepada mereka yang berotoritas lebih rendah. Biasanya kita beranggapan bahwa informasi bergerak dari manajemen kepada para pegawai; namun, dalam organisasi kebanyakan hubungan ada pada kelompok manajemen. Gambar 1 menunjukkan bagaimana struktur komunikasi sebuah universitas mempunyai enam tingkat manajemen dan hanya satu tingkat operatif. Organisasi (termasuk organisasi perguruan tinggi) sebagai kerangka kekayaan (frame work) menunjukkan adanya pembagian tugas antara orang-orang di dalam organisasi itu, dan dapat diklasifikasikan sebagai tenaga pimpinan dan tenaga yang dipimpin. Untuk menyelenggarakan dan mengawasi pelaksanaan tujuan yang akan dicapai, manajer atau administrator mengadakan peraturan sedemikian rupa sehingga ia tidak perlu berkomunikasi langsung dengan seluruh karyawan. Ia membuat kelompok-kelompok menurut jenis pekerjaannya dan mengangkat seseorang sebagai penanggung jawab atas kelompoknya. Dengan demikian, pimpinan cukup berkomunikasi dengan para penanggung jawab kelompok. Jumlah kelompok dan besarnya kelompok tergantung pada besar kecilnya organisasi. (Soleh Sumirat, 2000: hal 4.2 - 4.3)

Sebagai contoh, Universitas Padjajaran-Bandung memiliki 12 Fakultas (termasuk program pascasarjana). Pimpinan Universitas terdiri dari Rektor dan Pembantu Rektor (I, II, III, IV). Kelompok-kelompok Fakultas dipimpin oleh para Dekan (program regular), Direktur (pascasarjana), Ketua (Program Diploma dan Ekstension). Sub unit terdiri dari jurusan atau program studi. Rektor tidak perlu berkomunikasi langsung dengan para Ketua Jurusan/Program Studi, tetapi cukup dengan para Dekan. Bentuknya berupa rapat Rektor dengan Dekan.

\section{Gambar 2. Jumlah Perguruan Tinggi Negeri dan Swasta dan Sub Jumlah Empat Bentuk Organisasi Perguruan Tinggi.}

\begin{tabular}{|c|c|}
\hline *) Perguruan Tinggi Negeri & -) Perguruan Tinggi Swasta \\
\hline $\begin{array}{lrr}\text { Universitas } & 46 \\
\text { Institut } & 6 & \\
\text { Sekolah Tinggi } & 4 & \\
\text { Politeknik } & \underline{26} & \\
\text { Jumlah } & 82 & \\
\text { Dibawah kewenangan } & \text { Direktorat } \\
\text { Jenderal (Ditjen) Perguruan Tinggi } \\
\text { Depdiknas. }\end{array}$ & \begin{tabular}{lc} 
Universitas & 50 \\
Institut & 10 \\
Sekolah Tinggi & 135 \\
Politeknik & $\frac{9}{204}$ \\
Jumlah & \multicolumn{2}{c}{ Dumberat } \\
Dibawah kewenangan Direktora \\
Jenderal Pendidikan Tinggi, 12 \\
Koordinator Perguruan Tinggi \\
Swasta (Kopetis) 12 wilayah di \\
Indonesia.
\end{tabular} \\
\hline $\begin{array}{l}\text { Data. Tanggal } 08-2011 ; 08-16,6: 05 \\
\text { hwija@depkeu go.id }\end{array}$ & $\begin{array}{l}\text { Data. http// id.wikipedia.org/wiki. } \\
\text { Daftar } \\
\text { perguruan tinggi swasta di } \\
\text { Jakarta. }\end{array}$ \\
\hline
\end{tabular}


Rapat Rektor dengan para dosen di setiap Fakultas bukan merupakan rapat pimpinan dengan penanggung jawab kelompoknya, karena dosen bukan pejabat struktural organisasi perguruan tinggi, namun hanya sebagai pejabat fungsional universitas; seperti Penyuluh (Departemen Pertanian), Juru penerang (Departemen Penerangan).

Dengan semakin menggelembungnya sumberdaya manusia pada suatu organisasi, sedangkan jabatan struktural sangat terbatas, maka sebaiknya diperbanyak jabatan fungsional, sehingga iklim kerja dapat berjalan dengan baik, tanpa menimbulkan gejolak atau konflik karena tidak tersedianya jabatan. Anda dapat melihat pula bagaimana titik berat dalam komunikasi organisasi seringkali bergerak ke arah komunikasi manajerial yang perhatian utamanya adalah komunikasi ke bawah, membawa informasi melalui kelompok manajemen dan kepada kelompok operatif. Betapapun luas dan kompleksnya kelompok-kelompok manajemen organisasi perguruan tinggi di Indonesia, dalam menyalurkan informasi yang berkesinambungan dan sulit, dapat dengan berkaca pada tabel jumlah 286 perguruan tinggi negeri dan swasta diseluruh Indonesia.

Ada dua masalah utama: (1) jenis informasi apa yang dibawa dari tingkat manajemen kepada para pegawai dan (2) bagaimana informasi tersebut disediakan.

Betapa luasnya tantangan kepemimpinan manajerial komunikasi organisasi ditingkat kelompok manajemen 286 perguruan tinggi bila dibandingkan dengan satu organisasi perguruan tinggi Universitas Padjajaran dalam contoh di halaman sebelumnya; dan komunikasi kebawah membawa informasi melalui kelompok manajemen dan kepada kelompok operatif para Dosen; dalam struktur organisasi 286 perguruan tinggi negeri dan swasta.

\section{Gambar 3. Empat Arah Komunikasi Organisasi}

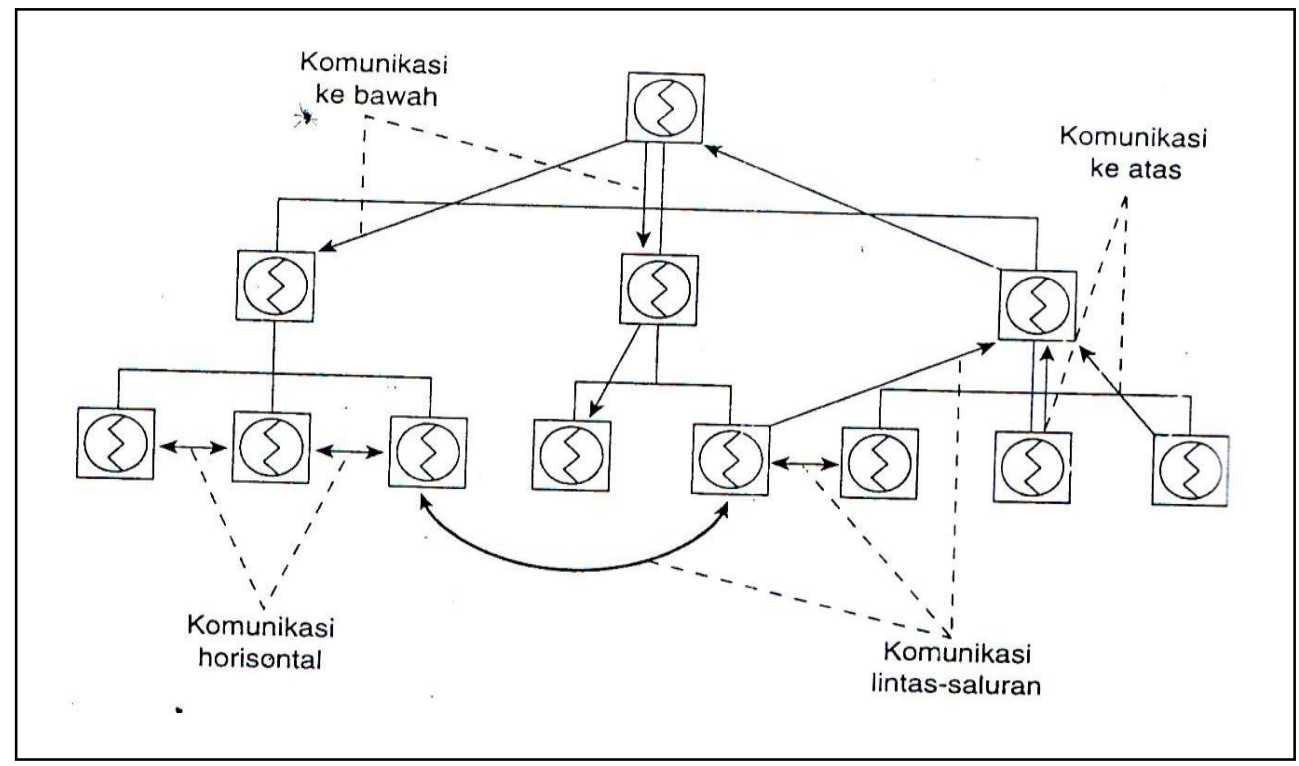


Gambar 2 menunjukkan luas dan kompleksnya sub jumlah organisasi perguruan tinggi pada empat kelompok perguruan tinggi: universitas, institute, sekolah tinggi, dan Politeknik.

\section{Permasalahan Pokok}

Berdasarkan uraian latar belakang diatas maka permasalahan pokoknya pada motivasi kepemimpinan manajerial sebagai salah satu indikator yang digunakan manajer dan pimpinan mempengaruhi sifat perilaku orang lain atau bawahannya serta motif mereka dalam rangka mewujudkan produktivitas dan efisiensi; dan gaya kepemimpinan yang mendasari perhatian manajer pada tugas produksi pada manusia atau kombinasi keduanya mencapai tujuan misinya, dan pada konsistensi cara bekerja sama mewujudkan gaya kepemimpinan yang membantu komunikasi organisasional manajemen.

\section{Landasan Teori}

\section{Teori $X$ dan Teori $Y$}

Asumsi tentang gaya kepemimpinan seorang manajer mempengaruhi bawahan atau pengikutnya didasarkan pada beberapa asumsi tentang orang-orang dan motif mereka.

Mc Gregor (1967) dalam R. Wayne Pace dan Don F. Fauls (2002:278) mengemukakan dua asumsi bahwa manajer dan pimpinan memiliki tendensi untuk melakukan apa yang disebut Teori X dan Teori Y; menentukan dua perangkat asumsi atau pendapat bipolar atau saling berlawanan yang cenderung dipakai oleh para pemimpin mengenai orang lain, bahwa manajer dan pimpinan memiliki toleransi untuk melakukannya. Disimpulkannya ada dua anggapan yang saling berlawanan yang timbul di kalangan manajer.

Strategi kepemimpinan pimpinan dan manajer dipengaruhi oleh anggapan-anggapan seorang pemimpin tentang sifat dasar manusia.

\section{1) Teori $X$}

Teori $\mathrm{X}$ berkesimpulan, bahwa rata-rata pembawaan manusia malas atau tidak menyukai pekerjaan dan menghindarnya bila mungkin, maka orang harus diwaspadai, diawasi, diarahkan atau diancam dengan hukuman agar melaksanakan tugasnya dalam mencapai tujuan organisasi; rata-rata manusia lebih suka diarahkan ingin menghindari tanggung jawab, mempunyai imbalan yang relatif kecil dan menginginkan keamanan/jaminan hidup diatas segalanya. Teori $X$ berasumsi bahwa karyawan adalah sebagai alat produksi dimotivasi karena takut akan hukuman, atau dibangkitkan minat karena uang dan keamanan. Manajer yang memandang para pekerja seperti ini, cenderung lebih tertutup, membuat dan memberlakukan peraturan secara ketat, dan menggunakan ancaman hukuman dengan tujuan memotivasi pekerja.

Asumsi teori $\mathrm{X}$ tampaknya diturunkan dari pendapat mengenai manusia sebagai suatu mesin, yang amat memerlukan pengendalian dari luar. Secara ringkas sebagai berikut. 
(1) Kebanyakan orang berpendapat bahwa pekerjaan adalah sesuatu yang tidak menyenangkan dan berusaha menghindarinya.

(2) Kebanyakan orang lebih suka diperintah dan seringkali harus dipaksa untuk melakukan pekerjaan mereka.

(3) Kebanyakan orang tidak ambisius, tidak ingin maju dan tidak menginginkan tanggung jawab.

(4) Kebanyakan orang dimotivasi terutama oleh keinginan mereka untuk memenuhi kebutuhan pokok dan kebutuhan akan rasa aman.

(5) Kebanyakan orang harus dikendalikan secara ketat dan tidak mampu menyelesaikan masalah dalam organisasi.

Tampaknya cukup beralasan untuk mengatakan bahwa seorang pemimpin yang berpegang pada Teori $X$ akan menganggap orang sebagai suatu alat produksi, dimotivasikan oleh ketakutan akan hukuman atau oleh kebutuhannya akan uang dan rasa aman. Manajer yang memandang pegawai dengan cara seperti ini, cenderung mengawasi mereka dengan ketat, membuat dan menjalankan aturan dengan keras, dan menggunakan ancaman hukuman sebagai alat untuk memotivasi mereka.

Strategi seorang pemimpin yang menganut anggapan Teori $\mathrm{X}$ akan cenderung menyukai gaya kepemimpinan otokratik.

\section{Teori $\mathbf{Y}$}

Asumsi teori $\mathrm{Y}$ cenderung berasal dari pendapat mengenai manusia sebagai organisme biologis yang tumbuh, berkembang, dan melakukan pengendalian terhadap diri mereka sendiri. Teori $Y$ beranggapan penggunaan fisik dan mental dalam bekerja adalah kodrat manusia seperti bermain atau istirahat. Asumsi teori Y secara ringkas sebagai berikut:

(1) Kebanyakan orang berpendapat bahwa kerja adalah sesuatu yang alamiah seperti bermain atau istirahat. Bila pekerjaan tidak menyenangkan, mungkin itu karena cara melakukan pekerjaan tersebut dalam organisasi.

(2) Kebanyakan orang merasa bahwa pengendalian diri sendiri amat diperlukan supaya pekerjaan dilakukan dengan baik.

(3) Kebanyakan orang dimotivasi terutama oleh keinginan mereka untuk diterima lingkungan, mendapat pengakuan, dan merasa berprestasi, seperti juga oleh kebutuhan mereka akan uang untuk memenuhi kebutuhan pokok dan rasa aman.

(4) Kebanyakan orang ingin menerima bahkan menginginkan suatu tanggung jawab bila mereka memperoleh bimbingan, pengelolaan dan kepemimpinan yang tepat.

(5) Kebanyakan orang mempunyai kemampuan untuk menyelesaikan masalah secara kreatif dalam organisasi.

Pemimpin yang mendasari tindakannya atau gayanya pada Teori $\mathrm{Y}$ beranggapan bahwa pegawai mempunyai kebutuhan yang beraneka ragam. Mereka percaya bahwa tugas mereka adalah mengatur dan mengelola sehingga 
baik organisasi maupun pegawai dapat memenuhi kebutuhannya. Dalam teori $Y$, manajer berasumsi bahwa tujuan perorangan dan tujuan organisasi dapat berjalan selaras. Namun, beberapa bukti menyatakan bahwa kedua-duanya tidak dapat dicapai dalam konteks organisasi. Beberapa tujuan pribadi dan beberapa tujuan organisasi mungkin bertentangan. Namun, manajer yang menerima asumsi Teori $\mathrm{Y}$, bekerja bersama-sama pegawai untuk mencapai tujuan organisasi, mendorong pegawai untuk berperan serta dalam proses pengambilan keputusan, dan mencoba mewujudkan peningkatan.

Strategi pemimpin yang menganut Teori $\mathrm{Y}$ lebih menyukai gaya kepemimpinan partisipatif atau demokratif.

\section{Teori Gaya Manajerial, Kisi Kepemimpinan}

Salah satu teori gaya kepemimpinan yang paling banyak didiskusikan adalah yang dikemukakan Blake dan Mouton (1964), yang semula disebut kisi manajerial (managerial grid) tapi kini disebut kisi kepemimpinan (1991) dapat ditelaah pada Gambar 4 mengenai Kisi-Kisi manajerial berikut. Kisi ini berasal dari hal-hal yang mendasari perhatian manajer: perhatiannya pada tugas atau pada hal-hal yang telah direncanakan untuk diselesaikan oleh organisasi, dan perhatian kepada orang-orang dan unsur-unsur organisasi yang mempengaruhi mereka. Kisi ini menggambarkan bagaimana perhatian pemimpin pada tugas dan pada manusia sehingga menciptakan gaya pengelolaan dan kepemimpinan. Kisi-kisi manajerial adalah orientasi para manajer pada tugas dan karyawan serta kombinasi antara keduanya secara ekstrim. Sumbu horizontal memberi perhatian terhadap produksi dan sumbu vertikal memberi perhatian terhadap karyawan. Didalamnya terdapat lima gaya kepemimpinan. Secara teoritis penggunaan Sembilan titik dalam kisi-kisi, dengan identifikasi 81 kombinasi yang digunakan secara meluas sebagai peralatan pelatihan. Gambar 4 menunjukkan bagaimana lima gaya kepemimpinan dasar dari kisi-kisi atau jaringan yang berkaitan satu sama lain. Kelima jenis gaya ekstrim yang dikemukakan model kisi disajikan secara singkat berikut ini.

Manajer1,1 pada sudut kiri bawah pada kisi-kisi digambarkan sebagai manajer "turun tahta" - gaya pengalah- (impoverished style). Gaya ini ditandai oleh kurangnya perhatian terhadap karyawan maupun produksi dan tugas. Pemimpin yang lemah cenderung menerima keputusan orang lain, menyetujui pendapat, sikap, dan gagasan-gagasan orang lain, serta menghindari sikap memihak. Bila terjadi konflik, pemimpin jenis ini tetap netral dan berdiri di luar masalah. Dengan tetap netral, pemimpin gaya pengalah jarang terlibat. Pemimpin pengalah hanya berusaha sedikit untuk mengatasi keadaan.

Manajer 5,5 Gaya pemimpin pertengahan (middle-of-the-road-style). Gaya ini ditandai oleh perhatian yang seimbang terhadap produksi dan manusia atau karyawan. Pemimpin jenis ini mencari cara-cara yang dapat berguna, meskipun mungkin tidak sempurna, untuk memecahkan masalah. Tipenya menggunakan tawar menawar dalam menyelesaikan pekerjaan.

Bila ada pendapat, gagasan, dan sikap yang berbeda dengan yang dianutnya, pemimpin gaya pertengahan mungkin saja menjadi bimbang dan 
mencari jalan untuk menghindari ketegangan. Pemimpin seperti ini akan berusaha untuk mempertahankan keadaan tetap baik.

9,9 Gaya tim (team style). Gaya ini ditandai oleh perhatian yang tinggi terhadap tugas dan manusia. Pemimpin tim amat menghargai keputusan yang logis dan kreatif sebagai hasil dari pengertian dan kesepakatan anggota organisasi. Pemimpin tim mendengarkan dan mencari gagasan, pendapat dan sikap yang berbeda dari yang dianutnya. Pemimpin tim mempunyai keyakinan kuat mengenai apa-apa yang harus dia lakukan, tetapi memberi respons pada gagasan orang lain yang logis dengan mengubah pendapatnya. Bila terjadi konflik, pemimpin tim mencoba memeriksa alasan-alasan timbulnya perbedaan dan mencari penyebab utamanya. Dalam keadaan marah, seorang pemimpin tim dapat mengendalikan dirinya meskipun kadang-kadang terlihat jengkel. Pemimpin jenis ini mempunyai rasa humor yang besar meskipun mungkin ia sedang dalam keadaan tertekan, dan ia menunjukkan usaha keras serta mengikutsertakan orang lain untuk ikut bergabung bersamanya. Pemimpin tim mampu menunjukkan kebutuhan akan saling mempecayai dan saling menghargai diantara sesama anggota tim, juga menghargai pekerjaan. Inti pengarahan kerjanya kepercayaan dan saling memahami tujuan organisasi. Manajemen tim yang demokratik memberi perhatian penuh pada produksi, semangat kerja dan kepuasan karyawan melalui pendekatan partisipatif atau tim. Gaya ini adalah perilaku kepemimpinan yang efektif. Pendekatan ini meningkatkan prestasi dalam hampir semua situasi.

\section{Gambar 4. Kisi-Kisi Manajerial}

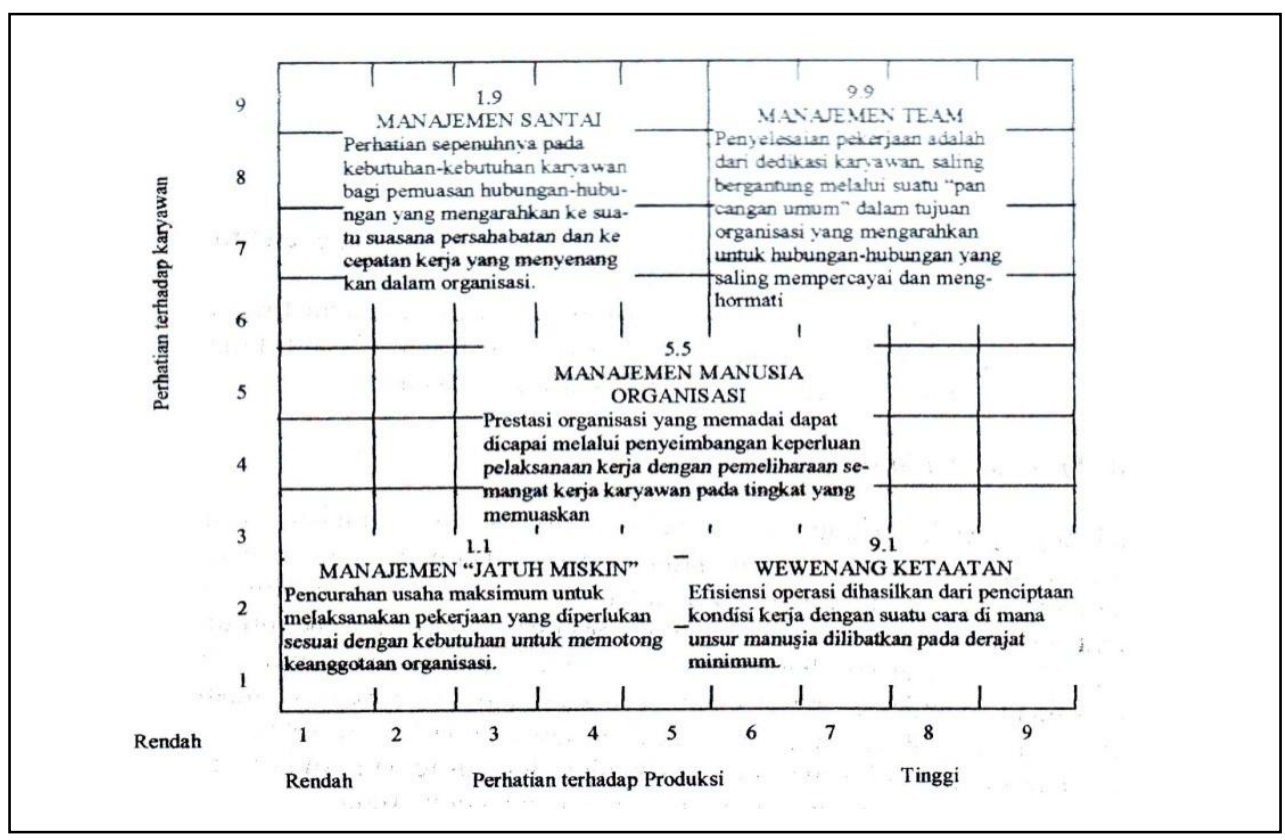


1,9 Gaya santai (country club style). Gaya ini ditandai oleh rendahnya perhatian terhadap tugas dan perhatian yang tinggi terhadap manusia. Pemimpin jenis ini amat menghargai hubungan baik diantara sesama orang. Ia lebih suka mnerima pendapat, sikap, dan gagasan orang lain daripada memaksakan kehendaknya. Ia menghindari terjadinya konflik, tapi bila ini tidak dapat dihindari, ia mencoba untuk melunakkan perasaan orang dan menjaga agar mereka tetap bekerja sama. Pemimpin gaya santai selalu bersikap hangat dan ramah untuk mengurangi ketegangan yang ditimbulkan oleh adanya gangguan. Pemimpin seperti ini lebih banyak bersikap menolong daripada memimpin. Kepemimpinan "santai" serba mengijinkan dengan tekanan pada pemeliharaan keuangan dan kepuasan karyawan.

9,1 Gaya kerja (task style). Gaya ini ditandai oleh perhatian yang tinggi terhadap pelaksanaan kerja tetapi amat kurang memperhatikan manusianya. Pemimpin gaya kerja amat menghargai keputusan yang telah dibuat. Pemimpin gaya kerja adalah orang yang perhatian utamanya adalah melaksanakan dan menyelesaikan pekerjaan secara efisien. Pemimpin jenis ini cenderung untuk mempertahankan gagasannya, pendapatnya, serta sikapnya meskipun kadangkadang ini dihasilkan dengan cara menekan orang lain. Bila timbul konflik, pemimpin jenis ini cenderung menghentikannya atau menenangkan posisinya dengan cara membela diri, berkeras pada pendiriannya atau mengulangi konflik dengan sejumlah argumentasi baru. Bila sesuatu tidak berjalan dengan seharusnya, pemimpin gaya kerja akan memacu dirinya juga orang lainnya supaya semuanya kembali berjalan dengan baik. Gaya manajer ini, laksana seorang otokrat, pemegang tugas yang keras dan pengawasan tertutup yang dikenal dengan manajemen tugas atau otoriter yang perhatiannya tinggi terhadap produksi dan efisiensi, tetapi rendah terhadap karyawan.

Menurut Blake dan Mouton, gaya tim 9,9 merupakan gaya kepemimpinan yang paling disukai. Kepemimpinan gaya tim berdasarkan pada integrasi efektif dari dua kepentingan, yaitu pekerjaan dan manusia. Pada umumnya, kepemimpinan gaya tim berasumsi bahwa orang akan menghasilkan sesuatu yang terbaik bilamana mereka memperoleh kesempatan untuk melakukan pekerjaan yang berarti. Di balik gaya 9,9 ini tersembunyi kesepakatan untuk melibatkan anggota organisasi dalam pengambilan keputusan, dengan maksud mempergunakan kemampuan mereka untuk memperoleh hasil terbaik yang mungkin dicapai.

\section{Kerangka Pemikiran: Pengertian dan Pendekatan Kepemimpinan}

Pengertian kepemimpinan berangkat dari banyak definisi dan teori pendekatan kepemimpinan atau leadership dalam berbagai sektor kehidupan baik politik, ekonomi, maupun sosial. Kepemimpinan manajerial dianggap cukup relevan dengan motivasi dan gaya kepemimpinan komunikasi organisasi (Massie J. L., 1983). Kepemimpinan manajerial adalah suatu proses pengarahan dan pemberian pengaruh pada kegiatan-kegiatan dalam sekelompok anggota yang saling berhubungan dalam tugasnya. Yaitu: 
- Kepemimpinan menyangkut orang lain (bawahan atau pengikut) yang menerima pengarahan dari pemimpin dan merekalah yang membantu menentukan kedudukan pemimpin dan membuat proses kepemimpinannya dapat berlangsung,

- Kepemimpinan menyangkut suatu pembagian kekuasaan yang tidak seimbang antara pemimpin dan anggota kelompok: serta pemimpin berwenang mengarahkan anggota kelompok, sedangkan kelompok tidak dapat mengarahkan pemimpin,

- Pemimpin juga menggunakan pengaruh bukan hanya sekedar memerintah bawahan melainkan ikut menentukan cara bagaimana bawahan memenuhi tugasnya dengan cepat.

Perlu dibedakan kepemimpinan, dengan manajemen yang mencakup kepemimpinan. Kepemimpinan adalah bagian penting dari manajemen, tetapi tidak sama dengan manajemen. Kepemimpinan merupakan kemampuan seseorang mempengaruhi orang-orang lain agar bekerja mencapai tujuan dan sasaran. Manajemen mencakup kepemimpinan, tetapi juga mencakup fungsifungsi lain seperti perencanaan, pengorganisasian, pengarahan, dan pengawasan (Planning, Organizing, Actuating, Controlling -POAC).

Dikenal tiga jenis pendekatan kepemimpinan: (1) Sifat, (2) Perilaku, dan (3) Situasional (contingency).

(1) Pendekatan Sifat-sifat yang penting mencakup energy, pandangan, pengetahuan dan kecerdasan, imajinasi, kepercayaan diri, integritas, kepandaian berbicara, pengendalian dan keseimbangan mental maupun emosional, bentuk fisik, pergaulan sosial dan persahabatan, motivasi, antusiasme, berani, dan sebagainya. Pandangan lain mengikhtisarkan empat sifat utama suksesnya kepemimpinan organisasi:

- Kecerdasan,

- Kedewasaan dan keluwesan hubungan sosial,

- Motivasi diri dan dorongan berprestasi, dan

- Sikap-sikap hubungan manusiawi.

Di pihak lain, ada perbedaan keterbatasan sifat-sifat kepemimpinan jika kita meneliti tokoh-tokoh, negarawan seperti Napoleon, Mahatmagandi, yang dalam berbagai hal berbeda satu dengan yang lain sehingga tidak tampak sifat umum pada tokoh-tokoh tersebut.

(2) Pendekatan perilaku kepemimpinan muncul karena sifat-sifat tidak dapat menjelaskan apa yang menyebabkan kepemimpinan efektif. Lalu diupayakan menentukan apa yang dilakukan oleh para pemimpin seperti: perilaku bagaimana mereka mendelegasikan tugas, berkomunikasi dengan memotivasi bawahan. Perilaku ini dapat dipelajari atau dikembangkan sehingga dapat dilatih dalam kepemimpinan yang tepat agar efektif. Pendekatan perilaku memusatkan pada dua aspek, yaitu fungsi-fungsi dan gaya-gaya kepemimpinan sebagai berikut:

- Fungsi-fungsi pemimpin melakukan dua fungsi utama: tugas sasaran, informasi, dan pendapat atau pemecahan masalah dan tugas 
pemeliharaan kelompok sosial dalam arti penerimaan kelompok lain, penengah dari yang berbeda pendapat.

- Gaya-gaya kepemimpinan meliputi orientasi tugas, melalui gerak, tindakan, komunikasi kepada mengarahkan bawahan, dan berorientasi kepada karyawan (memotivasinya) dan produksi; dengan cara kerja sama dengan orang yang konsisten melalui apa yang dikatakannya (bahasa) dan apa yang diperbuatnya (tindakan), seseorang membantu orang-orang lainnya, dan cara seseorang bersikap didepan orang lain melalui gaya kerja.

(3) Tindakan situasional berpandangan bahwa pendekatan kesifatan dan perilaku pada penjelasan (1) dan (2) sebelumnya belum sepenuhnya menjelaskan kepemimpinan dan tidak ada satu pun gaya kepemimpinan yang tepat bagi setiap manajer dalam seluruh kondisi.

Pendekatan situasional (contigency) itulah yang dapat menggambarkan gaya itu yang bergantung pada faktor-faktor situasi, karyawan, tugas, organisasi, dan variable lingkungan lainnya. Ada tiga variable kritis yang mempengaruhi gaya pemimpin: pemimpin, pengikut atau bawahan, serta situasi, yang ketiganya saling berhubungan dan berinteraksi seperti pada gambar berikut:

\section{Gambar 5. Hubungan Antara Pimpinan, Bawahan dan Situasi}

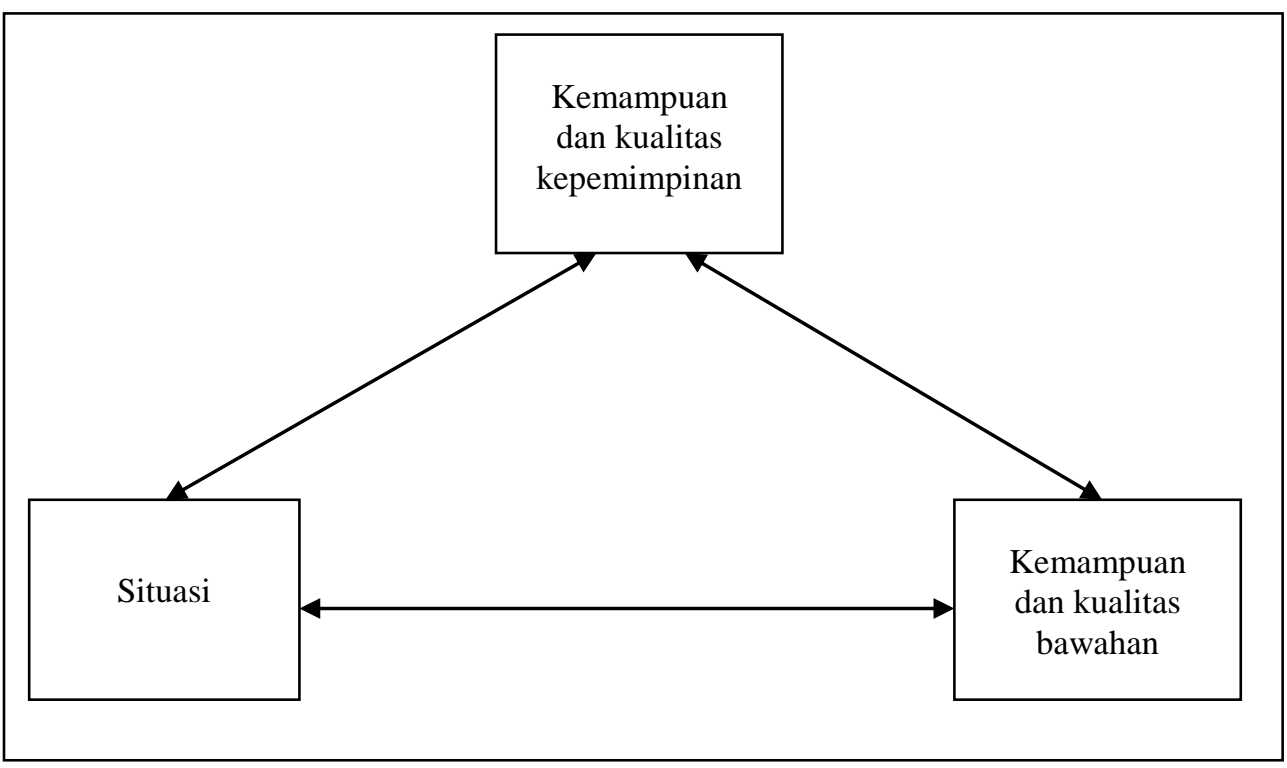


Selanjutnya dapat dipahami melalui variabel yang lebih banyak yang diklasifikasikan sebagai faktor makro dan faktor mikro. Secara lebih jelas pada gambar berikut:

\section{Gambar 6. Faktor-faktor yang Mempengaruhi Perilaku Kepemimpinan}

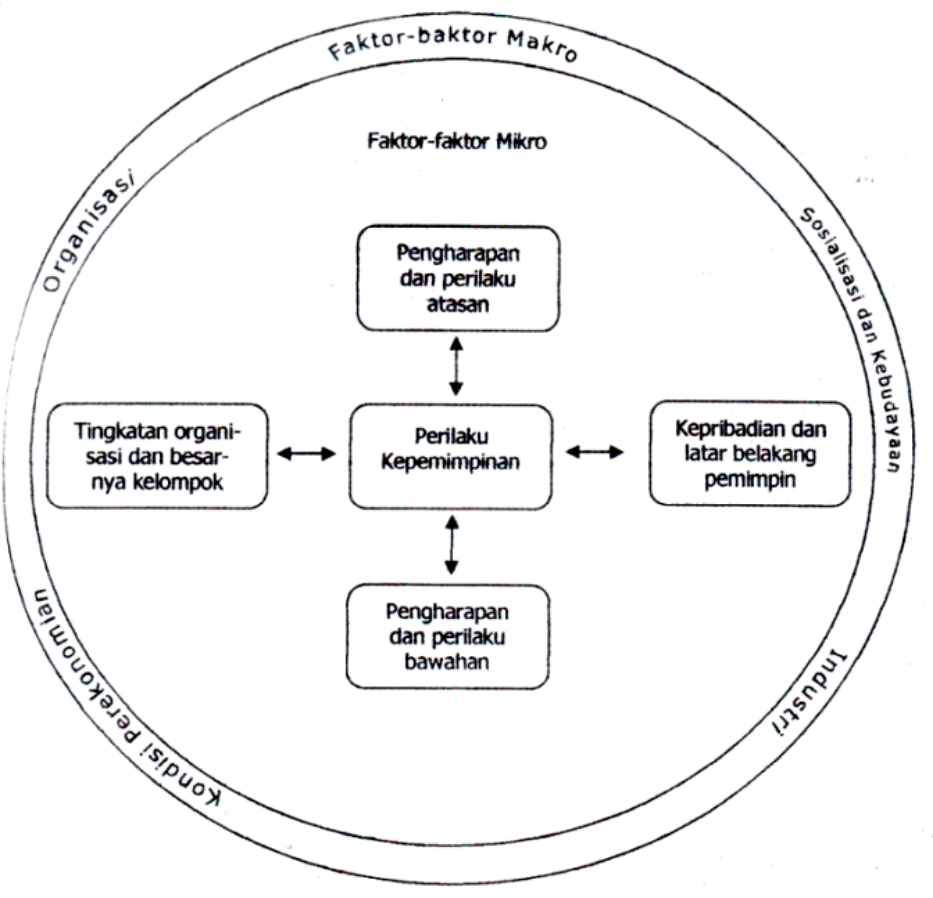

\section{Pengalaman Organisasional}

Salah satu sumber pengalaman yang dapat membentuk perilaku administrasi seseorang adalah peristiwa yang mungkin pernah dilaluinya pada organisasi yang lain, baik secara langsung maupun tidak (Sondang P. Siagian, 2003:62). Yang dimaksud dengan pengalaman langsung adalah apabila seseorang yang pernah bekerja pada suatu organisasi, lalu oleh karena sesuatu hal meninggalkan organisasi itu dan pindah ke organisasi yang lain. Sedangkan dengan pengalaman tidak langsung adalah peristiwa yang diamati dan diikuti oleh seseorang pada suatu organisasi meskipun yang bersangkutan sendiri tidak menjadi anggota daripada organisasi dimana peristiwa yang diamati dan diikuti itu terjadi.

Belajar dari pengalaman dengan demikian berarti bahwa baik peristiwa yang manis maupun yang pahit kedua-duanya memegang peranan dalam pembentukan perilaku administrasi seseorang. Yang manis hendaknya menjadi atau dapat dijadikan sebagai bahan pelajaran untuk bersikap wajar dalam hal 
seseorang "menang" dalam perjuangan hidup. Yang pahit hendaknya dijadikan sebagai faktor motivasional untuk meningkatkan kemampuan menghadapi masalah secara rasional dan dengan "kepala dingin dan dada yang lapang".

Hanya saja mungkin pengalaman yang pahit beserta dampaknya perlu lebih mendapat perhatian ketimbang pengalaman yang manis. Biasanya pengalaman pahit lebih berbekas ketimbang pengalaman manis yang relatif lebih mudah untuk dilupakan orang. Dalam rangka pembentukan perilaku administrasi yang diinginkan, pengalaman pahit sering meninggalkan "luka" yang apabila disembuhkan secara tepat, dapat menimbulkan pandangan-pandangan yang positif terhadap organisasi dan orang-orang lain di dalam organisasi. Menjadikan pengalaman pahit itu menjadi guru yang baik tidak mudah, akan tetapi bukannya mustahil. Inilah salah satu tantangan kepemimpinan manajerial organisasional yang harus dihadapi oleh setiap pimpinan.

\section{Contoh Kasus Pertama:}

Penulis bersama rekan empat Dosen Tetap dalam kelompok manajemen Panitia Revisi Kurikulum dibawah pimpinan Ketua Program Studi Ilmu Komunikasi (Prodi IKOM), Fakultas Ilmu Sosial dan Ilmu Politik (FISIPOL) Universitas Kristen Indonesia (UKI) Jakarta, termasuk sekretaris; penulis melakukan tugas kegiatan revisi pengembangan kurikulum baru untuk Tahun Akademik 2011 - 2015, selama 8 (delapan) bulan (contoh kasus pertama). Dilanjutkan dengan kegiatan Rapat Kerja Tahunan selama 3 (tiga) hari: tanggal 18 20 Juli 2011 (contoh kasus pertama) Panitia Revisi Kurikulum antara pimpinan dengan dosen.

Dalam kedudukan dan tugas organisasional selaku Koordinator pemetaan kurikulum Perminatan Humas dan Periklanan melakukan dan membahas makalah dan rumusan 3 (tiga) kegiatan : (1) kajian; (2) studi banding dan (3) loka karya dengan para rekan Dosen Tidak Tetap IKOM dan dengan para Nara Sumber (contoh kasus pertama), selama 8 (delapan) bulan; Nopember, Desember 2011 Januari sampai Juni 2011 di Kampus UKI Cawang Jakarta (Lampiran 1 jadwal Kegiatannya).

Tiga kegiatan organisasional Panitia tersebut diselenggarakan melalui forum komunikasi rapat-rapat, pertemuan, diskusi, wawancara mendalam dan terbuka, penyajian uraian menyeluruh, pertukaran pandangan, dan penilaian paradigma atas fenomena struktur kurikulum Program S1, Kompetensi Utama, distribusi bobot SKS Mata Kuliah per semester; Studi banding kompetensi IKOM dan Laboratorium Perguruan Tinggi lainnya: UI, UT Jakarta, UNAIR Surabaya, dan Universitas Moestopo Beragama Jakarta.

Forum komunikasi organisasional ini berlangsung antar anggota kelompok dengan pimpinan manajemen kaprodi IKOM sebanyak 8 (delapan) kali dan oleh Dekan dihadiri 5 (lima) kali selama 8 (delapan) bulan. 
Sebagai anggota kelompok manajemen Panitia Revisi Kurikulum pernah mengalami pengalaman pahit tidak disetujui pimpinan mengadakan studi banding berkomunikasi langsung dengan universitas-universitas yang bersangkutan melalui surat perintah jalan (SPJ) dinas. Pengalaman pahit ini berpengaruh negatif dalam pembentukan perilaku manajerial administratif yang kemudian dihadapi saja dengan sikap wajar secara positif. Pengalaman pahit ini dijadikan sebagai fakta motivasional meningkatkan kemampuan atau menjawab tantangan kepemimpinan manajerial kedepannya ialah tetap mewujudkan produktifitas dan efisiensi mencapai tujuan visi misi Fakultas.

Disisi lain suatu pelajaran pengalaman menghadapi pimpinan yang kurang perhatiannya kepada rekan anggota kelompok manajemen Panitia Revisi Kurikulum dalam melaksanakan tiga tugas kegiatannya. Namun pada akhir kegiatan dapatlah rapat Panitia menyelesaikan revisi kurikulum Prodi IKOM untuk Tahun Akademik 2011-2015 pada tanggal 15 Juli 2011.

Ternyata akhirnya kelompok manajemen Panitia dibawah pimpinan Kaprodi IKOM dan Dekan, telah mampu memberi perhatian yang tinggi terhadap tugas dan kelompoknya melakukan gaya kepemimpinan tim, Pimpinan disela-sela rapat, sering menampilkan rasa humor, saling mempercayai dan saling menghargai diantara tim dalam pekerjaannya. Itulah contoh kasus pertama.

Contoh kasus pertama lainnya, penulis bersama-sama Dosen Dosen IKOM dan HI FISIPOL-UKI, diundang menghadiri ikut serta dalam Rapat Kerja Tahunan (setiap lima tahun sekali) selama tiga hari tanggal 18 - 20 Juli, dibawah pimpinan Dekan dan kedua Kaprodi IKOM dan HI bertempat di Berkat Anugerah Resort Gunung Geulis Bogor agenda pokok, melakukan analisis PICA (Problem Identification and Corective Actions) terhadap :

(1) Rencana dan program kerja 2010/2011

(2) Pengesahan Manajemen kerja 2011 - 2016,

- Activity plan 2011/2012,

- Kurikulum baru Prodi IKOM dan HI tahun akademik 2011/2012, dan

- Buku Pedoman Akademik FISIPOL serta Buku Pedoman Penulisan Skripsi.

Proses pengarahan strategi dan manajemen oleh Dekan disertai diskusi hangat masukan-masukan, kritik, dan pimpinan Prodi IKOM dan HI masingmasing pimpinan dengan gaya kepemimpinannya selama 3 (tiga) hari, berlangsung dalam proses pengarahan dan pemberian pengaruh peserta raker pada kegiatan-kegiatan dalam kelompok peserta rapat kerja yang saling berhubungan tugasnya. Begitulah proses gaya kepemimpinan manajerial Dekan dan para Kaprodi masing-masing menggunakan pengaruh antar sesama kelompok kepada para Dosen kelompok operatif.

Dalam proses melakukan analisis PICA terhadap 3 (tiga) agenda pokoknya yang berlangsung di forum rapat kerja tersebut, bergerak ke arah komunikasi manajerial yang perhatian utamanya kebawah, ke kelompok operatif para Dosen peserta raker. Semua informasi bagaimana melakukan pekerjaan dalam program 
kerja tahunan mengenai kurikulum, misalnya kebijakan dan praktek organisasinya.

\section{Contoh Kasus Kedua:}

Pengalaman bekerja di Inspektorat Jenderal (Itjen Depdikbud) Departeman Pendidikan dan Kebudayaan (Kementrian Pendidikan Nasional sekarang) selaku Kepala Bagian (Kabag) Perencanaan Sekretaris Itjen, merangkap Kepala Pimpinan Program (Pimpro) Pengawasan, tetap dalam status jabatan fungsional Lektor Kepala Madya, waktu itu selama 5 (lima) tahun, tahun 1980-1985 Itjen Depdikbud mengawasi penyimpangan dan menindak lanjutnya di sejumlah 21 (propinsi) menjalankan tugas pemerintahan RI sebagai Aparat Pengawasan Fungsional (APFP) Departemen Pendidikan Kebudayaan. Secara keseluruhan APFP mencakup seluruh wilayah RI guna menunjang pengendalian intern/manajemen setiap tubuh organisasi pemerintah yang ada; dalam hal ini pengendalian intern seluruh unit 286 perguruan tinggi negeri maupun swasta (a.l. Depdikbud) Direktorat Jenderal Pendidikan Fungsi membawahi - sekarang tahun 2011 - membawahi 286 organisasi perguruan tinggi negeri dan swasta.

Kelompok manajemen : Sekretaris Itjen, atasan langsung Kabag Perencanaan dan Inspektur Jenderal (atasan langsung Kabag Perencanaan selaku Pemimpin Proyek Pengawasan/operatif bawahan) yang diawasi seluruh Indonesia. Unit Perguruan Tinggi Negeri (82 unit) dan Perguruan Tinggi Swasta (204 unit) dibawah kewenangan Koordinator Perguruan Tinggi Swasta (Kopertis/wilayah I - XII). Pengalaman langsung didalam kelompok manajemen pengawasan ditingkat birokrasi pimpinan maupun dengan unit-unit operatif pada dasarnya mengalami peristiwa hubungan dengan kelompok pimpinan dan operatif mengalami tipe-tipe gaya kepemimpinan atasan yang kadang-kadang demokratik, otokratik, netral dan gaya tim.

\section{Kesimpulan}

Kepemimpinan manajerial organisasi utamanya dibawah pimpinan para Rektor dengan para pembantu Rektor (Dekan dan Kepala-kepala Program Studi) mengelola 82 perguruan tinggi negeri, 204 perguruan tinggi swasta bentuk Universitas, Institut, Sekolah Tinggi, Politeknik, secara mendesak melaksanakan amanat sistem pendidikan nasional (Undang-Undang RI No. 20 Tahun 2003) menerapkan Standar Nasional, dan mengelola otonomi perguruan tinggi secara strategis (Peraturan Pemerintah RI No. 19 Tahun 2005).

Itulah momentum, waktunya menumbuhkan, memelihara, menyesuaikan, mengadakan perubahan, melengkapi kebebasan dan perusahaan birokrasi akademik strategi manajemen komunikasi organisasionalnya, terutama merespons faktor lingkungan pengaruh pada kebijaksanaan pendidikan tinggi dalam pengembangan sumber daya manusia, mencerdaskan bangsa, komersialisasi manajemen pendidikan. 
Disamping itu oleh pengaruh dua faktor; oleh (1) kurang adanya motivasi pimpinan organisasi perguruan tinggi terhadap aktualisasi nilai-nilai agama, kebudayaan berdasarkan Pancasila dan Undang-Undang Dasar 1945 dikalangan internal dan eksternal kepemimpinan manajerial perguruan tinggi serta (2) kurang tanggapnya terhadap tantangan tuntutan perubahan pengembangan karakter dan nilai-nilai kebangsaan (National and Character building). Kedua faktor ini adalah indikator tantangan kepemimpinan yang perlu direspons semua pimpinan organisasi perguruan tinggi dewasa ini.

\section{Daftar Pustaka}

Downs, Carl and Tony Hain.1978. Productivity and Communication Year Book 5.

Doughty Philip. 1990. Human Resources Development and Management- IUC-IDIA Seminar Syracuse Universitas Trisakti. Jakarta.

Goldhaber, Gerald M.1986. Organizational Communication. Iowa: C. Brown Publisher

Grunig, Larrisa and James, E. Grunig. 1991. Public Relations Research Annual.

Greenbaum Howard, H. Falcion Raymond Land, Hellwey Susan A.1984. Organizational Communication Volume 9.

Katta and Khan. 1986. The Social Psychology of Organization, New York: John Wiley and Sons, Inc.

Kreps, Garry L. 1986. Organizational Communication, Foundation for Human Resources Development. New Jersey: Englewood Cliffs.

Rumondor Alex, 2007. Manajemen Hubungan Masyarakat Modul Fisipol UKI Th 2007 - SOP Update Package Learning Pembuatan Modul.

Rumondor Alex, 2007. Komunikasi Antar Budaya Modul Fisipol UKI, Th 2007 SDP Update Package Learning Pembuatan Modul.

Rumondor Alex. 2001. Communication Climate Predictor of Overall Job Satisfication among the Sales Representatives: A Study of Organizational Communication, Human Resource Development and Management among the Sales Representative in the Company Organization in Jakarta. Disertasi.

Soemirat, Soleh, Elvinaus Ardianto, Jessy Ratna seminar (2000), Komunikasi Organisasional - Materi Pokok SKOM 4329 (3SKS Modul 1-4) Universitas Terbuka 1996.

2000. Komunikasi Organisasional. Modul UT SKOM 4329/3 SKS/Modul 1-9.

Sondang P. Siagan. 1986. Organisasi Kepemimpinan dan Perilaku Administrasi. Jakarta: Penerbit Gunung Agung. 
Tabloit ASWA, Edisi II. 2001. "Fisipol Perlu Membenahi Diri?"

Wayne Pace R \& Don F. Faules. 2002. Deddy Mulyana (Ed). Komunikasi Organisasi Strategi Meningkatkan Kinerja Perusahaan.

\section{Dokumentasi}

Himpunan Peraturan Indonesia Nomor 20 Th 2003 Sisdiknas: Sistem Pendidikan Nasional, 2006

Peraturan Pemerintah RI No. 19 Th 2005 Standar Nasional Pendidikan.

Peraturan Pemerintah RI No. 48 Th 2005, Pengangkatan Tenaga Honor menjadi Pegawai Negeri Sipil

Peraturan Menteri Pendidikan Nasional No.11 Th 2005 Tentang Buku Seks Pelajar.

hwija@depkeu.go.id. Daftar jumlah Perguruan Tinggi Negeri di Seluruh Indonesia 2011.

http/id.wikipedi.org/wiki. Daftar Jumlah Perguruan Tinggi Swasta di Jakarta. 